\title{
TIMUR YANG MISTIS DAN BARAT YANG LOGIS: REPRESENTASI PASCAKOLONIAL DALAM CERPEN SUSUK KEKEBALAN (2010) KARYA HAN GAGAS
}

\author{
Ahmad Mustholih \\ Universitas Nasional \\ email: mustolihahmad@gmail.com \\ Hary Sulistyo \\ Universitas Sebelas Maret \\ email: sulistyohary@yahoo.com
}

\begin{abstract}
This research discusses the short stories of Susuk Kekebalan by Han Gagas with Edward $W$. Said's Orientalism theory. The story tells about the condition of the representation of the 1965 political conflict in Indonesia, especially between the defeated opposition parties during the coup in the inferior PKI group and the representation of the ruling government as a superior group representation. The relation of superiority and inferiority is a reflection between the dichotomy of binary opposition between West and East as the theory of Orientalism's view in which it is based on western perspective. Moreover, in the western perspective, the East is often analogous to the weak, mystical, the middle of nowhere, and illogical, while the West is the opposite of those terms. The method used in this sresearch is by looking at aspects of superiority and inferiority, the mystical and logical, and seeing the correlation with historical conditions especially with the historical aspect in the colonial era. The analysis of this research results in relevance between the West and East where the East is represented in Warok Wulunggeni and Warok Wirodigdo which is mystical and easy to compete in sheep. While the western representation in the smart Mister with gun, which is superior, and a representative of power. The conclusions of this study include, although the eastern in western perspective is in a weak position in the hierarchy of power, but on the other hand the eastern values such as loyal friends, night spirit, and mysticism by installing Susuk Kekebalan, make eastern representations have a deconstructive value against the point of view west.
\end{abstract}

Keywords: Susuk Kekebalan, superiority and inferiority, binary opposition West and East position

\begin{abstract}
ABSTRAK
Penelitian ini membahas cerpen Susuk Kekebalan (2010) karya Han Gagas dengan teori Orientalisme Edward W. Said. Cerpen tersebut bercerita mengenai kondisi representasi konflik politik 1965. Dalam konfilk itu, relasi superioritas dan inferioritas tersebut merupakan representasi antara dikotomi oposisi biner antara Barat dan Timur. Selain itu, dalam kacamata Barat, Timur sering kali dianalogikan sebagai pihak yang lemah, mistis, antah berantah, dan tidak logis, sedangkan Barat adalah oposisi biner yang sebaliknya. Penelitian ini melihat
\end{abstract}


aspek superioritas dan inferioritas, yang mistis dan logis, dan melihat korelasinya dengan kondisi historis khususnya dengan aspek kesejarahan di era kolonial. Timur direpresentasikan dalam diri Warok Wulunggeni dan Warok Wirodigdo, yang mistis dan mudah di adu domba. Representasi Barat dalam diri Bapak bersenapan yang cerdas, superior, dan representasi dari kekuasaan. Hasil penelitian ini adalah bahwa meskipun Timur dalam kacamata Barat berada dalam posisi lemah dalam hierarki kekuasaan, di sisi lain nilai-nilai Timur seperti setia kawan, jiwa ksatria, dan kemistisan dengan memasang susuk, membuat Timur memiliki nilai dekonstruktif terhadap sudut pandang Barat.

Kata kunci: Susuk kekebalan, superioritas dan inferioritas, oposisi biner Barat dan Timur

\section{PENDAHULUAN}

Pembacaan terhadap cerpen Susuk Kekebalan (2010) karya Han Gagas, mengingatkan pada dikotomi oposisi yang digagas oleh Edward W. Said dalam konsepnya mengenai orientalisme, yaitu adanya konsep Barat dan Timur dengan menggunakan sudut pandang Barat (Gandhi, 1998). Cerpen tersebut menarasikan dua kubu yang berseberangan secara ideologis antara kelompok Warok Wirodigdo dan Warok Wulunggeni yang terlibat dalam pertarungan. Keduanya sama-sama memiliki pengikut sehingga menghadirkan pertempuran ataupun konflik gagasan pada peristiwa akhir dalam cerpen.

Cerpen Susuk Kekebalan (2010) karya Han Gagas menceritakan konflik horizontal yang terjadi di Ponorogo, Jawa Timur. Meski cerpen tersebut ditulis pada tahun 2010, latar cerita yang diangkat adalah peristiwa konflik politik tahun 1965 di Indonesia. Melihat persoalan tekstual dalam cerpen Susuk Kekebalan, representasi ideologi masyarakat berkaitan dengan ideologi pro pemerintah dan ideologi yang melawan pemerintah ${ }^{1}$.

Di luar persoalan pro dan kontra tersebut, ada representasi budaya yang tercermin di dalam cerpen tersebut. Budaya yang dimaksud adalah relasi secara horizontal antara masyarakat Jawa, khususnya, dengan konteks konflik sporadis yang dipengaruhi oleh ketidaksepahaman cara berpikir. Secara

\footnotetext{
${ }^{1}$ Menurut Aprinus Salam (2018), trend banyaknya karya sastra yang mengangkat salah satunya mengenai isu 1965 di Indonesia setelah era Reformasi. Hal itu dikategorikan sebagai sastra traumatik menuju sastra heroik.
} 
khusus, hal itu diwujudkan dalam pandangan pemikiran atau ideologi. Karena persoalan perbedaan ideologi, kedua kelompok yang terepresentasikan di dalam cerpen tersebut berupaya saling membunuh dengan pembelaan masingmasing. Terlebih lagi, konflik itu semakin meruncing setelah adanya arahan dari tokoh Bapak bersenapan yang memengaruhi tokoh Warok Wirodigdo dan kelompok massanya. Hal itu ditunjukkan dengan menyerang dan berupaya menghabisi Warok Wulunggeni beserta para pengikutnya. Sulistyo (2018; 27) menjelaskan bahwa pesoalan sejarah mengenai dinamika masyarakat berhubungan dengan peristiwa konflik politik pada tahun 1965 di Ponorogo. Hal ini merupakan tema utama dalam cerpen Susuk Kekebalan (2010) karya Han Gagas. Konflik semacam ini juga ditemukan dalam berbagai cerita yang lainnya, seperti karya Ayu Utami tentang konsep agama di era reformasi dan konflik alam beserta manusianya dalam cerita pendek Pohon Jenawi (Steenbrink, 2014: 326-336).

Sudut pandang cerpen Susuk Kekebalan (2010) merupakan representasi kelompok inferior yang berusaha menyelamatkan diri dari amukan massa karena kondisi perlawanan yang tidak berimbang. Penokohan utama dalam cerpen tersebut melalui sudut pandang tokoh Aku yang bernama Hargo. Jalan mistis yang dipilih oleh tokoh Hargo dan Karso adalah tokoh yang berada dalam relasi kekuasaan inferior. Hal itu merupakan bentuk frustasi dan ketakutan atas ancaman kematian yang bisa datang sewaktu-waktu. Sebab, hal itu diwujudkan melalui serangan pihak lawan sebagaimana telah dialami oleh beberapa temannya. Mereka berupaya mencari pertolongan dengan cara memasang susuk kepada Warok Wirodigdo. Dia adalah guru spiritual yang juga satu kelompok dengan mereka, yaitu sama-sama sebagai simpatisan BRP (Barisan Reog Ponorogo).

Pemilihan cerpen Susuk Kekebalan (2010) karya Han Gagas sebagai representasi karya sastra "pinggiran" dikarenakan membawa isu-isu lokalitas, yakni tradisi di dalam masyarakat Ponorogo. Latar dan topik yang demikian ini sering kali dihindari dalam keusastraan Indonesia. Hal ini menjadi salah satu 
daya tarik untuk diteliti. Dharma (2018:42) mengutip pendapat Tony Day dan Keith Foulcher (2006) dan Derk (2006) mengatakan bahwa sastra Indonesia harus menggugat sastra nasional yang otoritatif sehingga sastra dengan perspektif daerah perlu untuk diketengahkan dalam arena kesusastraan di Indonesia. Hal ini serupa dengan yang dilakukan melalui oleh tema-tema suara lokalitas dalam sastra Indonesia (Muhamad, 2017: 34-40),

Dalam cerpen Susuk Kekebalan (2010), representasi amukan massa yang disebabkan oleh suatu hal bukan persoalan baru di dalam masyarakat Indonesia. Hal ini sudah menjadi "kebiasan" dalam masyarakat kelompok bawah, khususnya ketika terjadi konflik antar kelompok di dalam masyarakat. Hal ini terlebih diperkuat dengan aksi provokasi-provokasi. Bahkan, secara historis, hal itu tidak hanya terjadi pada kalangan masyarakat bawah, tetapi hal itu juga terjadi dalam elit kekuasaan pusat atau pemerintahan. Sebagai contohnya adalah representasi konflik antara kerajaan yang satu dengan kerajaan yang lainnya. Hal ini juga dibuktikan dengan munculnya perpecahan di dalam suatu kerajaan ataupun konflik internal. Faktor yang menyebabkannya adalah perbedaan kepentingan tertentu yang berdampak pada masyarakat. Misalnya, perpecahan Mataram Kartasura menjadi Kasunanan Surakarta dan Kasultanan Yogyakarta, yang sampai sekarang dampak tersebut masih terasa. Hal ini khususnya diwujudkan dalam sentimen etnisitas antar masyarakat di kedua kota tersebut. Masalah konflik etnisitas itu dapat dipadang sebagai bagian dari pewarisan kolonial, misal konflik etnisitas dengan masyarakat Tionghoa peranakan (Budianta, 2017:485-491, Meer dan Eickhoff, 2017:38-60).

Berkaitan dengan cerpen tersebut, hal menarik untuk dicermati adalah terjadinya konflik yang memiliki korelasi dengan warisan budaya kolonial. Secara khusus apabila melihat persoalan tekstual di dalam cerpen tersebut, ada relasi superior dan inferior, mistis, dan adanya politik adu domba yang diciptakan Barat yang superior dan pintar untuk memecah belah kedua kelompok ideologi di dalam cerpen tersebut. Hal ini dipandang sebagai 
gambaran atau ekspresi kelompok atau kebudayaan yang diwakili oleh pengarang. Pandangan yang demikian serupa dengan ungkapan bahwa kesastraan memberikan efek dan refleksi persoalan kolonial sebagaimana yang diungkapkan Spivak tentang kekerasan epistemisnya (Morton, 2008).

Apabila dikaitkan dengan persoalan kolonialisme di Indonesia, relasi superioritas dan inferioritas merupakan simbolisasi relasi antara koloni dan dikoloni atau penjajah dengan terjajah. Dalam hal ini, sebagaimana dikemukakan oleh Edward W. Said dalam bukunya berjudul Orientalisme (2001), dia menjelaskan bahwa terminologi antara negara penjajah dan yang dijajah dalam pandangan penjajah adalah adanya konsep Barat dan Timur (Susanto, 2011: 254-255). Barat dilambangkan dengan yang superior, pintar, logis, dan beradab. Timur dalam pandangan Barat direpresentasikan dengan posisi yang lemah, bodoh, tidak rasional, dan kurang beradab.

Seperti telah dibahas sebelumnya, ada pengklasifikasian keberadaan kubu Barat dan Timur dalam pandangan Barat sebagai koloni yang memiliki kekuasaan atas Timur. Lalu, berdasarkan dikotomi oposisi model Edward W. Said (2001), ada hal yang perlu dijabarkan lebih lanjut mengenai kelompok yang menempati posisi Barat (Occident) dan kelompok dalam posisi Timur (Orient). Hal ini perlu diperhatikan bahwa dalam naskah cerita pendek Susuk Kekebalan (2010) keduanya merupakan kelompok warok yang sama-sama sebagai orang Timur, dalam konteks ras dan tradisi. Akan tetapi, seperti halnya dalam pandangan pascakolonial, terminologi "pasca" berkaitan dengan ruang dan waktu dan konteks pemikiran atau ideologi (Lo dan Gilberth, 1998). Dengan demikian, di satu sisi, hal itu masih berhubungan dengan kolonialisme atau pascakolonial. Di sisi lain, konteks tersebut berada pada ruang dan waktu dalam konteks kolonialisme secara fisik sudah berakhir.

Studi pascakolonial berkaitan dengan dampak (dalam hal ini khususnya adalah budaya dan identitas) kolonialisme oleh kolonial di masa lampau terhadap masyarakat yang pernah dijajah (Lo dan Gilberth, 1998; 1-2). Hal ini berkaitan dengan jejak-jejak yang masih tertinggal, baik dalam budaya atau 
identitas yang ada dalam masyarakat. Kenyataan itu atau jejak-jejak itu merupakan pengaruh kolonialisme. Dalam konteks Indonesia, hal ini tentu berkaitan dengan mentalitas yang masih tertinggal sebagai warisan Belanda ataupun Inggris. Dengan demikian, terminologi postcolonial dalam analisis terhadap cerpen Susuk Kekebalan (2010) karya Han Gagas tidak selalu berkaitan dengan keberadaan Belanda/Inggris (Barat) secara fisik, melainkan sifat-sifat yang hadir karena "warisan" kolonialisme. Atau pun dengan kata lain, analisis atau pembacaan ini melihat jejak kolonialisme yang terekspresikan dalam karya sastra tersebut sebagai wakil dari kelompok masyarakat terpinggirkan dalam sejarah Indonesia.

Melihat permasalahan pada cerpen Susuk Kekebalan (2010) karya Han Gagas, ada sisi menarik yang dapat dikaitkan dengan perspektif pascakolonial. Pertama, hal ini berkaitan dengan dikotomi Barat dan Timur sebagai klasifikasi dalam perspektif teori Edward W. Said (2001), yang dapat dilihat pada peristiwa di dalam teks. Berkaitan dengan hal tersebut, persoalan yang dapat dilihat adalah relasi superioritas dengan inferioritas dan representasi dan identitas Barat dan Timur yang ada dalam cerpen tersebut. Kedua, hal yang lain berkaitan dengan kondisi historis dalam konteks penjajahan kolonial, yang memiliki kesamaan tipologi dengan refleksi persoalan yang ada dalam teks. Dua sisi ini merupakan reduksi dari perspektif teori Edward W. Said (2001). Hal tersebut dihubungkan dengan pemikiran tentang "orientalisme" (relasi yang terjajah dengan penjajah) sebagai sudut pandang dalam cerpen Susuk Kekebalan (2010). Hal ini dianggap sebagai permasalahan utama tulisan ini. Persoalan tersebut berhubungan dengan pandangan orientalisme. Orientalisme sebagai teori digunakan untuk melihat relasi superioritas dengan inferioritas dan representasi Barat dan Timur di dalam cerpen Susuk Kekebalan (2010) karya Han Gagas. Cerpen ini dijadikan sebagai objek material dalam penelitian ini.

Permasalahan dalam penelitian ini adalah representasi gagasan Barat dan Timur. Keberadaan Barat dalam cerpen tersebut terwakili melalui sifat yang terus-menerus direproduksi oleh masyarakat bekas koloni. Fakta tersebut 
menunjukkan bahwa warisan kolonial, mentalitas, dan bentuk-bentuknya sebagai representasi warisan budaya Barat dalam memandang Barat dan Timur. Hal itu dikemukakan oleh Edward W. Said (2001) dalam teorinya mengenai Orientalisme. Persoalan tersebut tampak hadir dalam teks sebagai representasi identitas dan budaya masyarakat pascakolonial. Di sisi lain, Timur yang selalu tampak rendah dan dipandang sebagai the other dalam kacamata Barat. Namun, mereka memiliki nilai-nilai lebih dan tidak dimiliki oleh Barat. Hal itupun tercermin dalam cerpen Susuk Kekebalan (2010) karya Han Gagas.

\section{TEORI DAN METODE PENELITIAN}

Edward W. Said (2001) pada dasarnya melakukan dekonstruksi terhadap oposisi biner, terutama pandangan kaum kolonialis (kaum orientalis) terhadap dunia Timur. Pandangan mereka bernilai negatif dan merupakan suatu konstruksi sosial budaya yang tidak terlepas dari kepentingan dan kekuasaan dari kaum kolonialis. Dengan demikian, hasil penelitian dan pemikiran kaum orientalis tidaklah bersifat netral (Susanto, 2011: 254-255).

Edward W. Said (2001) melalui penelitian yang diterbitkan dalam Orientalisme telah melakukan pembacaan terhadap teks-teks budaya (sastra), yakni tentang kekuatan kolonial Barat (Inggris dan Prancis) dalam mendefinisikan wilayah atau dunia yang lain, seperti Afrika Selatan dan Timur Tengah. Orient secara umum berarti Timur bukan sebagai Timur dalam wilayah melainkan cara Barat memandang dan memikirkan dunia Timur beserta isinya. Orientalisme dengan demikian diartikan cara Barat memandang dunia Timur (Susanto, 2011: 255).

Oposisi biner yang dikenalkan oleh Edward W. Said antara Barat dan Timur dengan istilah Occident dan Orient menunjukkan satu sifat yang negatif, yakni ada yang lebih unggul dan lebih rendah. Dalam konteks ini, Barat lebih unggul dari Timur sehingga tidak ada dikotomi pembagian yang setara. Atas dasar pembagian oposisi biner ini, Edward W. Said (2001) mengatakan bahwa Barat terutama kaum orientalis memandang Timur sebagai suatu konstruksi. 
Orientalisme sebagai sebuah fantasi Barat dalam mengamati dunia Timur yang tidak mendasarkan diri pada pengamatan yang sesungguhnya, tetapi hanya berdasar hasil konstruksi pikiran mereka yang bergerak dalam menentukan pandangan mereka terhadap dunia Timur (Susanto, 2011: 255).

Dampak terhadap kajian Orientalisme salah satunya adalah persoalan stereotipe dunia Timur. Dunia Timur beserta isinya menerima efek yang terus menerus terhadap gambaran yang diberikan oleh Barat. Orient atau Timur dikatakan sebagai sesuatu yang abadi yaitu Timur tidak bisa mengalami satu perubahan menuju masyarakat yang lebih baik. Sesuatu yang dicitrakan itu bersifat timeless, tanpa batas waktu. Hal-hal yang tergambar dalam kajian orientalisme itu sepanjang masa berlaku baik di masa lalu dan masa yang akan datang. Melalui penggambaran Timur yang misterius dan menakutkan, dunia Timur dicitrakan sebagai dunia yang liar dan ganas. Hal itu membawa implikasi pada oposisi biner antara Occident dan Orient. Bila Occident atau Barat digambarkan rasional, memiliki sensibilitas dan ramah, Orient atau Timur sebagai dunia yang irasional, luar biasa dan tentu saja liar. Mereka baik yang dilahirkan di masa lalu maupun dan masa yang datang mewarisi sifat dan moral yang negatif, malas, keras atau kejam, dan hal-hal buruk lainnya (Susanto, 2011: 257-258).

Faruk (2012) menjelaskan bahwa metode penelitian berkaitan dengan cara pemaknaan data berdasarkan hipotesis atas dasar variabel-variabel dan sudut pandang teoretis yang digunakan untuk menemukan hubungan antardata yang tidak dimunculkan secara langsung oleh data-data. Dengan demikian, teori Orientalisme Edward W. Said (2001) digunakan sebagai sudut pandang. Metode penelitian ini terbagi ke dalam tiga tahap. Pertama adalah melakukan identifikasi terhadap hal-hal yang merepresentasikan korelasi Barat dan Timur dalam cerpen Susuk Kekebalan (2010) karya Han Gagas. Hal itu berkaitan dengan relasi antara superior dan inferior, cara berpikir yang strategis dan cara berpikir yang kurang logis, sifat mistis, dan sikap adu domba sebagai representasi Barat terhadap Timur. Kedua adalah menghubungkan 
identitas Barat dan Timur dalam cerpen Susuk Kekebalan (2010) karya Han Gagas, yakni gagasan yang memiliki hubungan dengan kondisi kesejarahan di era penjajahan di Belanda. Hal ini dapat dilihat dengan terjadinya peristiwa yang mirip antara konteks di dalam teks dengan peristiwa historis yang terjadi di Hindia Belanda dan wacana lain yang lahir di era penjajahan Belanda. Ketiga adalah dekonstruksi Timur terhadap Barat seperti pandangan Edward W. Said (2001) dalam teorinya mengenai orientalisme. Di luar persoalan Barat yang mendefiniskan Timur dengan kacamata Barat, ada nilai-nilai Timur yang unggul dan tidak dimiliki oleh Barat. Nilai-nilai tersebut terepresentasikan dalam cerpen Susuk Kekebalan (2010) karya Han Gagas sebagai bentuk dekonstruksi nilai Timur terhadap Barat dalam kekuasan simbolik yang didominasi oleh Barat dengan berbagai keunggulan perspektifnya.

\section{HASIL DAN PEMBAHASAN}

\section{Dikotomi Barat dan Timurdalam Cerpen Susuk Kekebalan (2010) Karya Han}

\section{Gagas}

Dikotomi Barat dan Timur dalam cerpen Susuk Kekebalan (2010) karya Han Gagas terepresentasikan melalui cara berpikir dan mentalitas. Hal itu diwujudkan melalui sifat logis, pintar, dan dominan yang berbanding secara terbalik dengan sifat-sifat mistis, bodoh, dan lemah. Sifat-sifat tersebut dapat ditemukan di dalam cerpen ini. Cerpen ini sendiri awal mulanya diterbitkan di surat kabar Republika pada tahun 2010. Akhirnya, cerita pendek ini diterbitkan dalam bentuk buku kumpulan cerpen dengan judul Catatan Orang Gila (2014).

Cerpen Susuk Kekebalan (2010) memiliki latar peristiwa konflik politik 1965. Pengarang menarasikan rasa khawatir tokoh Hargo dan Karso setelah kematian teman-temannya, yang merupakan anggota kelompok BRP (Barisan Reog Ponorogo). BRP sendiri adalah lembaga bentukan Lekra (Lembaga Kebudayaan Rakyat) yang merupakan representasi PKI (Partai Komunis Indonesia) untuk mewadahi aktivitas para seniman. Kematian teman-temannya dikarenakan dampak dari peristiwa penculikan para jenderal di Jakarta yang 
dilakukan oleh kelompok yang diduga PKI. Dengan demikian, karena peristiwa kudeta yang dilakukan oleh PKI itu gagal, para simpatisan dari kalangan atas hingga bawah harus menerima dampaknya. Seperti halnya yang telah dialami oleh teman-teman tokoh Hargo dan Karso, beberapa simpatisan BRP harus meregang ajal. Hal ini berhubungan dengan tindakan kudeta yang gagal. Merekapun harus dihapuskan dari Indonesia.

Hal lain adalah pengejaran yang dilakukan oleh otoritas negara hingga ke daerah pelosok seperti Ponorogo. Secara historis, Madiun dan sekitarnya, termasuk Ponorogo, merupakan salah satu basis PKI. Sebagai akibatnya, banyak warok yang diangap terlibat dalam peristiwa politik tersebut ditangkap. ${ }^{2}$ Hal itu ditunjukkan melalui keberadaan BRP sebagai lembaga kesenian reog. Tentu saja, banyak seniman atau pecinta reog bersimpati dengan pergerakan kelompok BRP.

Cerpen tersebut menunjukkan bahwa konflik yang terjadi di Ponorogo merupakan perseteruan antara kelompok yang mendukung pemerintah dengan kelompok menjadi lawan pemerintah di Ponorogo. Warok Wirodigdo sebagai representasi dari pemerintah berseberangan dengan pandangan politik kelompok lawan pemerintah, yang diwakili oleh Warok Wulunggeni. Meski keduanya adalah warok yang sama-sama nguri-uri kesenian Reog, mereka bermusuhan dan tidak segan untuk saling membunuh karena perbedaan ideologi.

Selain kedua warok dan para pengikutnya, ada tokoh Bapak bersenapan dalam cerpen tersebut. Peran tokoh Bapak bersenapan dalam cerpen tidak signifikan, baik secara karakter maupun kehadirannya. Keberadaannya hanya dimunculkan melalui percakapan antara tokoh Warok Wirodigdo, yang mengatakan dirinya mendapat arahan dari Bapak bersenapan untuk menghabisi Warok Wulunggeni beserta para pengikutnya, seperti dalam kutipan berikut.

\footnotetext{
2 National Geographic Indonesia edisi 30 September 2015 mengangkat banyaknya seniman yang diperalat untuk kepentingan politik, salah satunya pengakuan Randimo, aktor kethoprak berusia 76 tahun berasal dari Prambanan.
} 


\footnotetext{
"Aku tak mau basa-basi! Kau selama ini yang menyokong BRP. Aku mengantarkan bapak ini untuk menangkapmu!" jawab Warok Wirodigdo

“Tapi apa salahku, Wiro?! Bukankah aku hanya berkesenian saja? Tak lebih!" Sikap Eyang Warok menegas.

"Aku tak peduli! Kata bapak ini, kau harus dilenyapkan!"

Warok Wirodigdo langsung menyerang. Semua orang menyingkir. Mereka tahu, senapan dan senjata tajam tak berguna dalam pertarungan itu. Ilmu kanuragan lah yang utama (Gagas, 2010)
}

Melalui kutipan tersebut, Bapak bersenapan memiliki peran yang signifikan dalam konflik tersebut. Meski dia tidak digambarkan secara jelas karakternya, keberadaannya dapat menggerakkan Warok Wirodigdo dan barisan massanya untuk memburu Warok Wulunggeni. Hal itu memperlihatkan bahwa ada relasi kekuasaan dalam diri Bapak bersenapan. Perannya dalam memengaruhi orang lain cukup penting dan hal ini merupakan representasi negara. Representasi itu menunjukkan relasi kekuatan yang superior bila dibandingkan dengan kelompok Warok Wulunggeni yang inferior, sebagai bagian dari kelompok yang kalah.

Relasi cerita tersebut, melalui konsep pascakolonial, adalah relasi antara superioritas dan inferioritas. Barat bersifat superior dan Timur bersifat inferior. Pertanyaan yang muncul adalah "pada diri siapa posisi superior itu ada dalam cerpen Susuk Kekebalan (2010) ini". Hal ini mengingat secara umum terdapat tiga karakter yang memiliki relasi kekuasaan. Karakter itu adalah Warok Wirodigdo, Warok Wulunggeni, dan Bapak bersenapan.

Meski Warok Wirodigdo tampak sebagai posisi yang superior di dalam peristiwa tersebut, posisi yang ditempati oleh Warok Wulunggeni adalah posisi sebagai Timur. Hal itu berkaitan dengan pandangan Edward W. Said (2001) yang mengatakan bahwa Timur adalah antah-berantah yang amuk dan mudah dikendalikan. Posisi Warok Wulunggeni dan Warok Wirodigdo dalam cerpen tersebut dapat diibaratkan dengan "ayam pejantan yang diadu oleh Bapak bersenapan". Hal ini dilakukan dengan tujuan untuk menyelesikan tugas dalam membasmi sisa-sisa kekuatan PKI di daerah-daerah. Di sisi lain, seperti halnya judul dalam tulisan ini yang berkaitan dengan "yang mistis", keduanya adalah representasi Timur yang mistis. Sebab, keduanya sama-sama memiliki 
dan mengagungkan ilmu kanuragan sebagai warok. Hal ini dapat dipandang sebagai sesuatu tidak logis dalam sudut pandang dunia Barat. Hal yang mendapat perhatian lainnya adalah kesadaran atas pandangan tersebut. Bapak bersenapan, mentalitas, dan cara berpikir berada posisi Barat, menggunakan cara Timur untuk mengalahkan Timur. Hal ini dilakukan dengan cara mengadu dua tokoh warok yang sama-sama tidak logis dan mistis. Sebab, kedua-duanya memiliki memiliki ilmu kanuragan.

Korelasi gagasan pascakolonial dengan cerpen Susuk Kekebalan adalah politik adu domba yang dilakukan oleh Bapak bersenapan terhadap Warok Wirodigdo dan Warok Wulunggeni. Hal itu disadari oleh Bapak bersenapan yang berposisi sebagai Barat yang logis, cerdas, dan dominan. Keadaan ini ditunjukkan melalui arahan dan instruksi sebagai representasi dari kekuasaan, yang dituruti oleh Warok Wirodigdo. Di sisi lain, keterlibatan Warok Wirodigdo untuk menumpas kelompok Warok Wulunggen sebagai representasi PKI dikarenakan warok diyakini memiliki ilmu kekebalan yang tidak mempan senjata tajam maupun peluru. Hal itu seperti dalam kutipan berikut ini.

\footnotetext{
"Hatiku langsung bergetar! Bagaimana tidak, berita kesaktiannya begitu menancap di benakku. Kabarnya, pada zaman perang, berkat Aji Pulosani dan Jimat Wesi Kuning, semua senapan Belanda tak mampu menembus tubuhnya dan hanya membuat tulangnya benjol-benjol karena pelor yang terpental. Dulu sewaktu aku kecil, pernah melihat aksinya mbarong (memanggul barong macan) di atap rumah, memanjat pohon kelapa dan turun meluncur dengan kepala menghadap ke bawah. Aksi yang tak masuk akal" (Gagas, 2010).
}

Kutipan tersebut menunjukkan bahwa Warok Wirodigdo adalah warok yang memiliki kekuatan. Dia berada dipihak kekuasan. Posisi dirinya serupa dengan Warok Wulunggeni, yang sama-sama sebagai seniman warok. Akan tetapi, lawan yang dihadapi oleh Bapak bersenapan adalah Warok Wulunggeni. Warok Wulunggeni adalah representasi representasi Timur, yang mistis. Dengan demikian, Bapak bersenapan membutuhkan "ayam jantan" yang dapat diadu untuk mengalahkan kesaktian Warok Wulunggeni. 
Kecerdikan Bapak bersenapan dalam peristiwa tersebut merupakan representasi Barat yang logis. Kesadaranya terhadap lawan yang tidak bisa dia kalahkan dengan senapan membuatnya memilih untuk melibatkan Timur yang lain (Warok Wirodigdo). Hal ini dibuktikan dengan kekalan Timur (Warok Wulunggeni), yang keduanya sama-sama mistis. Keberpihakan Warok Wirodigdo terhadap Bapak bersenapan sebagai representasi Barat diawali dengan bujukan atau hadiah dari Bapak bersenapan. Dengan sikap keteladanan dan hegemoni, hal ini membuat Warok Wirodigdo bersedia untuk menghabisi Warok Wulunggeni meskipun kedua-duanya sama-sama warok dan dalam satu dunia yang sama.

\section{Korelasi Historis Identitas Barat dan Timur dalam Cerpen Susuk Kekebalan (2010) Karya Han Gagas dengan Konteks Kolonialisme di Indonesia}

Korelasi konflik antara Warok Wulunggeni dan Warok Wirodigdo dalam cerpen Susuk Kekebalan (2010) merupakan representasi politik adu domba yang dilakukan oleh kolonialisme Belanda untuk berkuasa. Sebagai contoh adalah kasus peperangan dalam Kerajaan Mataram yang diawali dengan intrik Belanda yang menolak Pangeran Arya Mangkunegara sebagai putra mahkota Pakubuwono I (Amangkurat IV) yang jelas-jelas anti kolonial atau VOC (Vereenigde Oostindindische Compagnie). Belanda memilih adik dari Amangkurat IV untuk menjadi raja Pakubuwono II setelah putra mahkota Paku Buwono I diasingkan ke Srilanka. Raden Mas Said, sebagai putra Pangeran Arya Mangkunegara, (cucu Pang Buwono I), melakukan pemberontakan dan melawan Belanda sekaligus Mataram-Kartasura. Hal ini dikenal dengan dengan sebutan Geger Pacinan (Remmelink, 2002). Konflik tersebut diawali dengan "campur tangan" dan adu domba Belanda beserta kelompok yang mendukung kebijakan tersebut. Hal ini dikarenakan memiliki segala kepentingan yang menolak perpindahan kekuasaan dari Paku Buwono II kepada Raden Mas Said sebagai ahli waris yang sah. Hal itu menciptakan perpecahan hingga akhirnya lahir dua otoritas swapraja di Surakarta yaitu 
Kasunanan Surakarta dan Pura Mangkunegaran yang secara historis keduanya saudara.

Bapak bersenapan dengan segala kelebihannya adalah representasi Barat. Hal ini sesuai dengan bukti bahwa dia berhasil melakukan politik adu domba pada masa penjajahan. Bapak bersenapan memiliki sifat-sifat yang sama dengan Barat yaitu logis, pintar, dan dominan. Hal ini mampu menggerakkan Warok Wirodigdo untuk menyerang lawan politik negara. Di sisi lain, baik Warok Wirodigdo maupun Warok Wulunggeni pada dasarnya adalah samasama Timur. Hal ini memudahkan mereka diadu hingga saling membunuh.

Representasi itu menunjukan bahwa Timur yang antah-berantah dan amuk merupakan representasi dari identitas yang mudah berkhianat. Bahkan, pengkhianatan itu dilakukan terhadap bangsa dan orang terdekat. Hal itu dapat dilihat dalam percapakan keduanya ketika hendak bertempur. Percakapan itu menunjukkan dengan jelas bahwa Warok Wirodigdo dan Warok Wulunggeni pada dasarnya sudah akrab dan saling mengenal. Akan tetapi, desakan, hasutan, bujukan, perintah, dan mungkin juga karena hadiah, baik secara langsung atau tidak langsung, dari Bapak bersenapan sebagai repesentasi penguasa, Warok Wirodigdo tidak lagi memandang Warok Wulunggeni sebagai warok. Warok yang seperti dirinya yang sama-sama menjaga eksistensi seni tradisi dan keduanya berasal dari daerah yang sama yaitu Ponorogo sudah tidak dianggap dalam pikirannya.

Berdasarkan persoalan tersebut, melalui sudut pandang kolonialisme Belanda, hal itu serupa dengan novel Max Havelaar (1860) karya Multatuli, sebagai karya dari Edward Douwes Dekker. Novel tersebut mengungkap kecurangan Bupati Lebak, Raden Adipati Karta Natanegara yang dituduh oleh Edward Douwes Dekker telah melakukan sejumlah kecurangan. Kecurangan itu adalah menaikkan pajak dari jumlah semestinya, pajak yang telah diatur oleh pemerintah pada waktu itu. Bupati Lebak menaikkan pajak. Kenaikan itu berdampak terhadap dua hal. Pertama adalah pemenuhan tanggung jawab terhadap pemerintah Hindia-Belanda, yang berkuasa dengan pajak yang telah 
di tentukan. Kedua adalah kondisi yang membuatnya memperoleh untung dari sisa pajak yang telah dipunggut dari rakyatnya sendiri. Hal itu dijelaskan oleh Subagyo Sastrowardoyo (1983: 30-39) bahwa hal itu berhubungan dengan kekecewaan Edward Douwes Dekker yang akhirnya membuatnya dipindahtugaskan oleh atasannya seperti dalam kutipan berikut.

\begin{abstract}
"Kekecewaannya terakhir yang berhubungan dengan pekerjaan dinasnya terjadi pada tahun 1856, ketika baru saja diangkat sebagai asisten residen Lebak. Di sini ia mulai menuduh bupatinya, Raden Adipati Karta Natanegara, telah melakukan pemerasan dan penindasan terhadap rakyatnya sendiri dan perkara ini telah dilaporkan kepada residen, dan kemudian juga kepada gubernur jenderal. Kedua majikannya ini rupanya tidak yakin akan kebenaran Douwes Dekker, sedang ia pun tidak sedia memberikan bukti-buktinya" (Sastrowardoyo, 1983: 39)
\end{abstract}

Melalui kutipan tersebut, hal dapat dilihat melalui peristiwa yang terjadi di era kolonial dengan cerpen Susuk Kekebalan (2010) karya Han Gagas. Meskipun hal itu tidak secara jelas dihubungkan dengan sifat Bupati Lebak, yang dengan sadar melilit rakyatnya sendiri atas nama pajak dan mengambil keuntungan darinya, sikap hianat antara sesama pribumi merupakan representasi Timur sudah ada sejak zaman kolonial Belanda. Melihat konteks cerpen Susuk Kekebalan (2010) karya Han Gagas, hal itu menunjukkan hubungan dalam hal sifat, yakni sikap khianat Warok Wirodigdo. Sikap itu memilih untuk menuruti arahan Bapak bersenapan dan memusuhinya. Bahkan, sifat itu menjadikan sebuah perbuatan, yakni membunuh Warok Wulunggeni yang sesama Timur, sesama pribumi. Hal itu tidak menutup kemungkinan bahwa yang dia lakukan itu pada dasarnya hanya untuk meraih kekuasaan. Kekuasaan itu berada dalam arena dunia warok, yakni pengakuan atas kekuasaan warok di dalam lingkungannya sendiri, yakni BRP. Kondisi ini serupa dengan sikap Bupati Lebak yang berkuasa. Dia melakukan sebuah kebijakan untuk meraih kekayaan dan kekuasan tanpa terhadap rakyat sendiri. Dia menaikkan jumlah pajak dan melebihi batas yang telah ditentukan oleh pemerintah Hindia Belanda.

Narasi tentang Timur yang mistis atau tidak logis juga hadir dalam dalam novel-novel di era Hindia Belanda. Dalam Cerita Nyi Paina (1903) karya H. Kommer, novel itu menceritakan usaha seorang perempuan pribumi bernama 
Paina yang dipaksa menjadi gundik seorang Belanda, Tuan Briot, yang merupakan administratur di sebuah pabrik gula. Tuan Briot itu adalah atasan langsung dari Niti Atmojo, bapak dari Paina sendiri. Pada awalnya, kehidupan Niti sangatlah baik dan akhirnya difitnah Tuan Briot mencuri uang pabrik. Untuk menyelamatkan jabatannya, dia mengorbankan Paina agar bersedia menjadi nyai dari Tuan Briot.

Namun, sebelum menyerahkan diri kepada Tuan Briot, Nyai Paina mendatangi wabah penyakit cacar dan memeluk mereka. Hal ini bertujuan agar kelak Tuan Briot terkenal penyakit tersebut dan meninggal dunia. Akhirnya, tujuan tersebut tercapai. Nyai Paina berhasil membunuh Tuan Briot melalui usahanya tersebut. Hal ini menunjukkan sebuah perlawanan yang misterius dari sosok Nyai Paina. Sebab, kaum yang terjajah merupakan kelompok atau mahluk yang mistis juga dan reaksinya tidak terduga oleh penjajah.

\footnotetext{
“Dan kesempatan ini dipakai Briot untuk memeras Niti dan Paina agar menyerahkan diri padanya: Paina akan diambil sebagai nyai. Niti menolak, tetapi Paina sendiri kasihan pada nasib malang ayah dan keluarganya. Maka Paina bersedia menyerahkan diri kepada Briot. Tetapi penyerahan ini dilakukan dengan amat cerdik. Kebetulan waktu itu desa-desa sedang terserang wabah cacar. Maka malam sebelum penyerahannya pada Briot, Paina sengaja memeluk seorang penderita cacar yang gawat. Kemudian baru ia membiarkan dirinya dipeluk Briot. Taktik ini berhasil baik. Paina yang amat benci terhadap Briot berhasil melepaskan pembalasannya. Briot dan Paina tak lama kemudian terserang cacar yang hebat. Briot akhirnya mati karena sakit yang hebat ini, sedang Paina sendiri selamat meskipun wajahnya cacat oleh bekas cacar" (Sumardjo, 2004: 156)
}

Korelasi topik novel tesebut menunjukkan bahwa representasi Timur yang tidak logis dan cenderung mistis juga muncul dalam cerpen Susuk Kekebalan (2010). Hal ini berhubungan dengan upaya pemasangan susuk yang dilakukan oleh tokoh Hargo dan Karso. Pemasangan susuk itu bertujuan untuk menyelamatkan dirinya dari pengejaran lawan politik, yang ingin membunuh mereka. Meski dalam cerpen tersebut digambarkan konflik batin yang dialami oleh tokoh Hargo, hal itu bertentangan dengan keyakinan dalam beragama. Akan tetapi, kekhawatiran atas keselamatan tersebut diselesaikan dengan cara berpikir yang tidak logis. Hal itu diwujudkan dengan pemasangan susuk yang 
dianggap memiliki kekuatan gaib atau mistis dan tidak logis. Peristiwa tersebut tercermin dalam kutipan berikut ini.

\begin{abstract}
“Eyang Warok menyorongkan lepek dan gelas ke depan kami. Tiba-tiba benakku disergap wejangan agar berhati-hati pada hal-hal syirik. Jauhi ilmu santet, Jaran Goyang, dan kebal. Aku gamang, namun ingatan tentang kematian Kang Pur, Parikesit, Sasmita, dan Tejo lebih kuat menancap dan menggulung wejangan itu" (Gagas, 2010).
\end{abstract}

Kutipan tersebut menunjukkan bahwa tindakan tidak logis pada akhirnya harus dilakukan. Hal ini bukan pada persoalan ketidakberdayaan, tetapi cara atau strategi dalam menghadapi situasi, sebuah situasi yang mengancam jiwanya. Jalan mistis dengan memasang susuk kekebalan yang tentunya dapat dinilai tidak logis itu pilih untuk menyelamatkan dirinya. Meski demikian, hal itu bertentangan dengan keyakinannya. Hal itu setipe pula dalam kondisi Cerita Nyi Paina karya H. Kommer. Hal ini dibuktikan dengan tindakan yang dianggap tidak logis dari Nyai Paina yang menyakiti dirinya sendiri. Dia melawan kekuasaan kolonial melalui Tuan Briopt dengan cara menjangkiti dirinya dengan virus cacar. Baginya, dia berhal atas tubuh dan kekuasaannya. Ketidaklogisan itu dilakukan atas dasar ketidakmampuannya dalam menghadapi kekuatan Barat yang superior. Hal itu juga tercermin dalam cerpen Susuk Kekebalan (2010) karya Han Gagas khususnya yang dijalani oleh tokoh Hargo dan Karso karena ketakutannya terhadap serangan ideologi yang dominan. Ideologi dan kekuasan itu adalah sebuah kekuasaan yang mengesahkan untuk memburu para simpatisan PKI seperti halnya mereka.

Korelasi identitas dalam kaitannya dengan studi pascakolonial adalah hubungan antara sifat-sifat yang terdapat pada kedua kubu, baik Barat maupun Timur. Keduanya memiliki nilai historis dengan era kolonial, khususnya Belanda. Relasi kekuasaan itu berkaitan dengan pandangan bahwa Barat (Belanda) selalu dominan dan superior terhadap Timur (pribumi). Bahkan, kekuatan itu mampu membuat aturan, perjanjian, dan kebijakan-kebijakan yang dominan dan mengatur atau mengobjektivitasi pribumi, sebagai representasi Timur. Peristiwa-peristiwa adu domba dilakukan oleh Belanda 
sebagai strategi untuk memecah-belah kekuatan Timur demi kepentingan mereka.

\section{Dekonstruksi Nilai Timur terhadap Barat dalam Cerpen Susuk Kekebalan (2010) Karya Han Gagas}

Dekonstruksi nilai Timur terhadap Barat merupakan upaya untuk menunjukkan oposisi biner. Oposisi itu mengeksplorasi bahwa Barat yang selalu tampak unggul dibandingkan Timur dan Timur yang selalu tampak rendah di mata Barat pada dasarnya sebuah konstruksi. Sebagai konsekuensi, sisi lain Timur yang memiliki nilai “unggul' dibandingkan dengan Barat perlu ditunjukkan. Nilai-nilai tersebut tidak dimiliki oleh Barat dan sebaliknya. Dalam konteks ini, kesetaraan atas identitas menjadi terwujud. Gagasan yang demikian ini tercermin dalam cerpen Susuk Kekebalan (2010) karya Han Gagas. Hal ini khususnya muncul dalam sifat dan sikap kelompok inferior sebagai representasi Timur dalam cerpen tersebut.

Bagian awal cerpen tersebut menunjukkan bahwa tokoh Hargo dan Karso tiba di rumah Eyang Warok (Warok Wulunggeni). Dalam kondisi yang serba menghawatirkan, mereka beberapa kali mengetuk pintu tokoh Karso dan akhirnya mendapatkan balasan dari Eyang Warok. Pada peristiwa itu, dalam kehati-hatian dan keadaan mencekam, seseorang dapat memperoleh kepercayaan hanya dengan menyebutkan nama guru dengan sebuah 'kode'. Kode ini juga menjadi pennada kelompok dan identitas bersama. Melalui kode itu, orang tersebut bisa dinilai berbahaya atau tidak oleh pemilik rumah karena termasuk kelompoknya atau bukan. Hal itu tersebut terhadirkan dalam kutipan bagian cerpen berikut ini.

\footnotetext{
"Hargo, Eyang Putri. Murid Kiai Basir," tambah Karso.

Aku tak tahu kenapa guru ngajiku itu harus disebut. Mungkin karena Kiai Basir adalah orang NU yang tersohor dan bisa diterima semua kalangan (Gagas, 2010).

Melalui kutipan tersebut, nilai Timur menunjukkan bahwa mereka memiliki sejumlah kode tertentu dalam menyembunyikan identitas mereka bersama. Sebagai contohnya adalah kepercayaan yang diberikan kepada
} 
muridnya untuk menggunakan kode tersebut. Meskipun pada awalnya, tokoh Eyang Putri sudah mengenal nama Hargo sebelumnya. Akan tetapi, identitas guru yang dimunculkan tampaknya bisa meningkatkan kepercayaan seseorang terhadap orang lain. Meskipun, kedatangan mereka dalam waku yang kurang tepat atau situasi yang kurang tepat.

Nilai Timur tersebut merupakan hal yang unik dan menarik. Pemberian kepercayaan terhadap seseorang, baik dan buruknya orang asing terhadap diri mereka, dilihat dari siapa gurunya. Dalam hal ini, seorang guru tentu memiliki representasi pemikiran dan sikap yang bisa dinilai secara umum. Bahkan, hal itu diyakini dapat mewujudkan dalam murid-muridnya.

Pada bagian selanjutnya, nilai Timur diwujudkan dalam keramahan dan kekeluargaan. Hal itu ditunjukkan dalam bentuk jamuan yang diberikan oleh pemilik rumah, yaitu Eyang Putri terhadap kedua tamunya. Dalam kondisi keamanan yang mencekam dan mengancam jiwa, hal itu berdampak terhadap aktivitas ekonomi dan aktivitas di luar rumah yang dibuktikan dengan sikap kehati-hatian mereka dalam menerima tamu. Eyang Putri masih memberikan suguhan terbaik dalam budaya masyarakat Jawa Timur, khususnya Ponorogo, yaitu menyuguhkan kopi hangat untuk para tamunya. Hal itu seperti dalam kutipan berikut ini.

\footnotetext{
"Ruang belakang terdengar menderakkan suara. Eyang Putri keluar membawa nampan berisi sepasang cangkir. Aroma kopi panas dan kental melayang, menari hingga rongga hidung, membangkitkan seleraku. Bau kopi khas hasil tumbukan sendiri.

"Silakan diminum."

“Terima kasih, Eyang Putri." (Gagas, 2010)
}

Kutipan tersebut menunjukkan bahwa sikap keramahan Timur dan penghormatan yang setinggi-tingginya terhadap tamu. Meski dalam kondisi yang sulit, kesadaran nilai Timur bahwa kedua orang yang berkunjung ke rumah Warok Wulunggeni adalah tamu. Sebagaimana budaya Timur, orang tersebut dihormati dengan jamuan yang baik. Hal itu tentu disadari bahwa kepedulian pemilik rumah terhadap para tamunya, yang berkaitan dengan 
hawa dingin di malam hari sehingga memberikan secangkir kopi hangat kepada tamu-tamunya. Hal ini memberikan rasa nyaman dan tentram.

Bagian selanjutnya menunjukkan sikap rasa saling menjaga nilai Timur yang tercermin dalam cerpen tersebut. Setelah pemasangan susuk yang dilakukan oleh Warok Wulunggeni, yaitu suami dari Eyang Putri. Hal ini dikarenakan kondisi yang mencekam atas kedatangan musuh yang sudah bergerombol di depan rumah. Eyang Putri sebagai pemilik rumah mempersilahkan para tamunya untuk lari melewati pintu belakang agar mereka selamat dari ancaman. Pemilik rumah tentu ingin memberikan keamanan terhadap para tamunya. Meskipun demikian, pada dasarnya, dua orang tamu tersebut adalah bagian kelompoknya. Mereka telah memiliki ilmu kanuragan, dalam hal kekebalan, sebab telah memasang susuk. Hal itu seperti dalam kutipan berikut ini.

"Kalian larilah lewat pintu belakang lalu susuri jalan setapak di dalam hutan! Kalian pasti selamat," suara Eyang Putri berirama cepat.

“Tidak, Eyang Putri. Kami di sini saja,” kata Karso (Gagas, 2010)

Kutipan tersebut menunjukkan bahwa ada rasa tanggung jawab pemilik rumah terhadap para tamunya. Di sisi lain, kedua tamu itu adalah Karso dan Hargo. Hal ini menunjukkan sikap setia kawan dan 'ingin membalas budi' atas kebaikan Warok Wulunggeni yang telah memasangkan susuk. Susuk itu diyakini telah memberikan efek kekebalan terhadap diri mereka. Dengan demikian, karena menyadari situasi yang gawat, kondisi jumlah musuh yang dominan, usia mereka yang jauh lebih muda, keyakinan akan kekebalan yang telah diperoleh, dan kesadaran merasa senasib dengan Eyang Warok dan istrinya, Karso dan Hargo memilih bertahan dan tidak menutup kemungkinan untuk ikut bertempur (dan mungkin akan tewas). Hal ini tentu saja akan berbeda bila dibandingkan untuk memilih pergi atau menyelamatkan diri sebagaimana arahan Eyang Putri.

Dekonstruksi nilai Timur terhadap Barat dalam cerpen tersebut sebagai representasi nilai-nilai Timur yang unggul dibandingkan Barat. Hal itu 
berkaitan dengan sikap satria dan kepedulian terhadap sesama yang ditunjukkan oleh tokoh Hargo seperti dalam kutipan berikut ini.

“Paku-paku menancapi pikiranku: antara lari melewati pintu belakang atau memilih pertarungan.

Dan, tubuhku bergetar! Serasa menebal pelan-pelan, membesar. Ototku mengencang, tulangku mengeras, berderakan. Aku merasa ilmu kebal merasuki tubuhku hingga sumsum tulang. Jantungku terpacu, nyaliku membaja! Aku mengamuk seperti banteng terluka" (Gagas, 2010).

Kutipan tersebut menunjukkan sikap kesetiakawanan dan keberanian Timur yang muncul dari diri tokoh Hargo. Ketika awalnya, dia selalu cemas dan takut terhadap kemungkinan terburuk yang terjadi. Khususnya, hal ini berhubungan dengan ancaman terhadap dirinya. Melihat situasi tersebut, peperangan yang tidak berimbang dan pihaknya terdesak, melalui keberanian dan kapasitasnya, Hargo memilih menerjunkan diri dalam pertempuran dan menyerang lawan-lawannya. Terlebih lagi, keberanian itu muncul setelah dia merasakan efek dari pemasangan susuk. Hal ini terlihat dalam wujud munculnya keberanian dan perubahan fisik yang ia rasakan dalam dirinya.

Bagian tersebut menunjukkan bahwa meskipun dia memasang susuk. Pada dasarnya, hal itu merupakan sikap mental yang kuno, tidak logis, dan mistis. Akan tetapi, pada sisi lain, hal itu memunculkan rasa percaya diri dan keteguhan hati untuk melawan ketika dirinya dan kelompoknya tertindas dan terdesak. Hargo pada awalnya ciut dalam hal nyali. Akhirnya, dia memiliki keberanian khususnya setelah merasakan efek dari pemasangan susuk. Tentu saja, hal ini merupakan representasi nilai positif Timur. Meski dalam sisi lain, pemasangan susuk adalah hal mistis dan tidak masuk logika. Akan tetapi, hal tersebut menunjukkan nilai positif dengan memunculkan keyakinan, keberanian, dan mengangkat nilai kesetiakawanan untuk membela kelompok dan orang-orang yang senasib dengan dirinya. 


\section{SIMPULAN}

Representasi dikotomi antara Barat dan Timur dalam sudut pandang dunia Barat, seperti dalam teori Edward W. Said (2010) yang terhadap cerpen Susuk Kekebalan (2010) karya Han Gagas ini ditunjukkan melalui sikap sebagai berikut. Barat digambarkan melalui sifat yang superior, memiliki pengaruh yang besar, dan cerdik. Hal itu tampak dalam upaya menumpas kelompok BRP sebagai representasi Timur yang inferior dan lemah atas konsekuensi kegagalan resistensi terhadap penguasa yang superior dalam bentuk kudeta. Pengaruh Barat digambarkan dengan keberhasilan melakukan hegemoni atas kelompok Warok Wirodigdo. Sebagai akibatnya, dengan segala kemampuannya, dia menghabisi Warok Wulunggeni. Kecerdikannya tampak dalam mengadu domba dua tokoh warok yang sama-sama memiliki ilmu kanuragan. Bapak bersenapan merupakan representasi Barat yang tentu tidak mampu mengalahkan Warok Wulunggeni yang kebal senjata tajam dan peluru.

Representasi Timur dalam cerpen tersebut tampak dalam diri Warok Wulunggeni beserta pengikutnya dan Warok Wirodigdo beserta barisan massanya. Sebagai stereotipe Timur yang gaib, keduanya mengagungkan ilmu kanuragan yang dalam perspektif Barat. Hal itu bersifat mistis dan tidak logis. Hal ini setipe dengan pandangan Barat dalam memandang Timur bahwa Timur adalah antah berantah. Di sisi lain, hal itu muncul dalam sifat mereka yang mudah terpancing dan diadu. Hal ini terwakili dari konsep Barat dalam tokoh Bapak bersenapan yang mengadu kedua warok tersebut.

Dekonstruksi atas nilai Timur yang unggul dan tidak muncul dalam sudut pandang Barat berhubungan dengan nilai-nilai kekeluargaan, kesetiakawanan, dan sikap satria. Khususnya, hal ini terlihat dalam dampak pemasangan susuk yang dinilai mistis dan tidak logis dalam kacamata Barat. Dalam kondisi yang serba mencekam, Warok Wulunggeni dan Nyi Warok menerima dua orang tamu, Hargo dan Karso. Hal itu menunjukkan sifat Timur yang memuliakan tamu. Kesetiakawanan tampak dalam sikap Karso yang juga merepresentasikan diri Hargo. Mereka menolak untuk menyelamatkan diri saat 
kedatangan rombongan Warok Wirodigdo atas kesadaran senasib dan merasa dalam pihak yang sama dengan Warok Wulunggeni. Sikap satria digambarkan dalam keputusan tokoh Hargo yang mengamuk untuk bertempur. Hal ini khususnya setelah merasakan efek perubahan dan energi dalam dirinya sebagai konsekuensi atas pemasangan susuk kekebalan. Meski pemasangan susuk dalam kacamata Barat tidak logis dan mistis, hal ini menunjukkan misteri dunia Timur. Hal ini menjadikan Hargo sebagai pribadi yang berjiwa satria dalam melawan musuh dan membela kelompoknya.

\section{DAFTAR PUSTAKA}

Budianta, M. (2017). "Culture, power, and identity: The case of Ang Hien Hoo, Malang" WACANA, Jurnal Ilmu Pengetahuan Budaya, Vol. 18, No. 2 (2017), hlm. 485-510.

Faruk. (2012). Metodologi penelitian sastra: sebuah penjelajahan awal. Yogyakarta: Pustaka Pelajar.

Gagas, H. (2010). Susuk kekebalan. Republika. Diakses pada tanggal 14 September 2018. https:/ / lakonhidup.com/2010/03/28/susuk-kekebalan/

Gagas, H. (2014). Catatan orang gila. Jakarta: Gramedia Pustaka Utama.

Gandhi, L. 1998. Postcolonial Theory: A Critical Introduction. Edinburgh: Edinburgh University Press.

Kommer, H. (1903). Cerita Nyi Paina. Batavia: A. Veit \& Co.

Maimunah, (2014). "Perlawanan Alam terhadap Kolonialisme da;am Cerpen Pohon Jenawi Karya Budi Darma". LITERA; Jurnal Penelitian Bahasa, Sastra, dan Pengajarannya, Vol. 13,No. 2, Oktober 2014, hlm. 326-337.

Meer, A van Der and Eickhoff, M. (2017). "Indonesian Chinese in the Netherlands and the legacies of violence in colonial and postcolonial Indonesia". WACANA, Jurnal Pengetahuan Budaya, Vol. 18, No. 1, 2017, hlm. 38-64.

Muhamad, A.B.R. (2017). "Suara-Suara Dari Pedalaman; Bias dan Dilema Identitas Nasionalisme dalam Novel Burung-Burung Manyar Sebuah Upaya Pencapaian Esensialisme Strategis" LINGUA, Vol. XIII, No.1, 2017, hlm. 34-50, http://journal.unnes.ac.id/mju/index.php/lingua

Morton, S. (2008). Gayatri C. Spivak: Etika, Subalternitas, E Kritik Penalaran Pascakolonial. (terjemahan: Wiwin Indriarti). Yogyakarta: Paraton.

Lo, J dan Gilberth, H. (1998). "Postcolonial Theory: Possibilites and Limitations" makalah pada An International Research Workshop University of Sydney, hlm. 1-8.

Remmelink, Willem. (2002). Perang Cina dan Runtuhnya Negara Jawa 1725-1734 (The Chinese War and the Collapse of the Javanese State 1725-1743). Yogyakarta: Jendela. 
Said, E.W. (2001). Orientalisme. (penerjemah: Asep Hikmat). Bandung Mizan.

Salam. A. (2018). Novel Indonesia setelah 1998: dari satra traumatik ke sastra heroik.. Academia Edu. June 10, 2018 www.academia.edu/8688782/Dari_Sastra_Traumatik_ke_Sastra_Heroik

Sastrowardoyo, S. (1983). Sastra Hindia Belanda dan kita. Jakarta: PN Balai Pustaka.

Satrya, H.D. (2018). Strategi Kiki Sulistyo dalam arena sastra Indonesia. Haluan Sastra Budaya. Vol 2 No 1. hlm. 41-59.

Steenbrink, Karel. (2014). "The reformasi of Ayu Utami: Attacking the monopoly of the great religions" WACANA; Jurnal Ilmu Pengetahuan Budaya, Vol. 15. No. 2 (2014), hlm. 351-366.

Sulistyo, H. (2018) Representasi konflik politik 1965: hegemoni dan dominasi negara dalam cerpen susuk kekebalan karya Han Gagas. Poetika: Jurnal Ilmu Sastra. Vol VI No. 1 Juli 2018, hlm. 26-43.

Sumardjo, J. (2004). Sastra melayu rendah masa awal. Yogyakarta: Galang Press.

Susanto, D. (2011). Pengantar teori sastra. Yogyakarta: CAPS. 